\section{Armant (Hermonthis)}

CHRISTOPHE THIERS

The ancient city of Armant (ancient Egyptian names: Iuny, Iunu, Iunu-shema, Iunu-Montu), the Greek Hermonthis and Coptic Ermont, was located $15 \mathrm{~km}$ south of Thebes on the west bank of the Nile (Mond and Myers 1940). Armant was the main city of the cult of MONTU, the falcon-headed god, protector of the Egyptian kingship and warrior, the main god of the Theban area since the 11th Dynasty, before the emergence of AMUN-RE at the beginning of the 12th Dynasty. He was worshipped here with his divine consort Rattawy/Tjenenet/ Iunyt. The temple of Montu dates back to the Middle and New Kingdom (see Figure 1). The limestone Middle Kingdom temple was completely dismantled and reused in the foundations of the late Ptolemaic temple, especially in the naos built in the name of PTOLEMY XII NEOS DIONYSOS AUlETES. Attested kings from the 11th and 12th Dynasties, found on temple reliefs or statues, are: Nebhepetra Mentuhotep II, Seankhkara Mentuhotep III, Amenemhat I, Senwosret (Sesostris) I and III, and Amenemhat III. The New Kingdom temple, made of limestone and sandstone, was erected by Thutmose III and Hatshepsut. The stones from this were later reused in the pronaos. Other kings from the 17th and 18th Dynasties are attested on stelae, statues, or blocs: KAMOSE (recent discovery of a historical stela), AHmose I, Amenhotep II, Thutmose IV, Amenhotep III, and Amenhotep IV (Theban talatats). Only the New Kingdom pylon was kept at its original location. It bears a famous depiction of a rhinoceros, several Nubians bringing African offerings, and a list of foreign countries. Until now, there is no clear evidence to support the traditional dating of this relief to the reign of Thutmose III, even if the famous stela Cairo JE 66377 (Beylage 2002: 157-69) of this king mentions a Nubian rhinoceros. On the eastern wing of the pylon, the remaining reliefs of the lower register bear the name of
Rameses III. On the eastern doorjamb of the gate, three lines of a five-line inscription in the name of Rameses II were recut by MERENPTAH, Amemmes, Sety II, Rameses IV (the sixth original line) and Rameses VI. The entrance wall (east side) bears the names of Rameses II (linked with the heb-sed festivals of Years 9, 10, and 11) (Mond and Myers 1940: 161-5). Merenptah also reused osirid colossi, generally thought to be made originally for Mentuhotep III. Nektanebo II also constructed at Armant (Mond and Myers 1940: 8). Even if some blocks from a gate (propylon?) bear the name of PTOLEMY VI PHILOMETOR, the temple of Montu-Ra seems to have been built anew during the reign of PTOLEMY XII, mostly attested in the crypts and on numerous scattered blocks.

The names of Roman emperors are present on scattered blocks (Nero, Vespasian, Hadrian) and at the gate of Bab el-Maganîn (Antoninus Pius) built at some distance from the main temenos. During the Coptic Period, an important settlement was build around the New Kingdom pylon and in the main courtyard, and a basilica was also erected south to the temple (Grossmann 1986).

Close to the temple and the sacred lake, a mammisi was built during the reign of CLEOPATRA VII and her son PTOLEMY XV CAESAR in honor of Rattawy and his son Harpra-thechild. This temple was completely dismantled

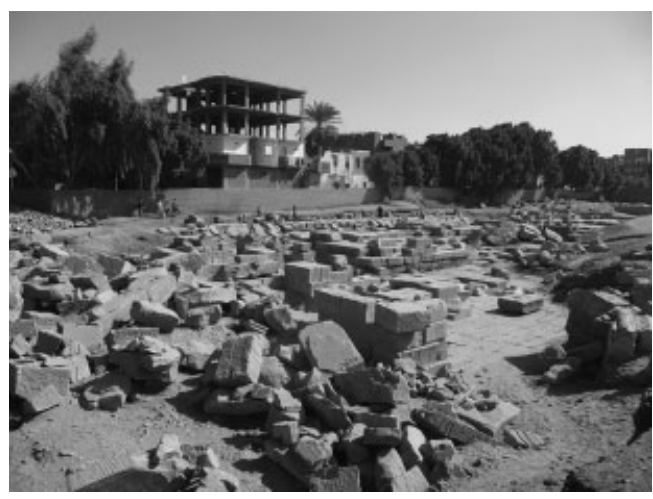

Figure 1 View of the Montu-Re temple at Armant. (C) Chr. Thiers. 
in 1861-2 to build the sugar cane factory at Armant.

The Bucheum/Bucheion, the burial place of the Buchis bulls, sacred to Montu, is located at the desert edge, north of the city (Mond and Myers 1934). The bulls were buried here from the time of Nektanebo II until the end of paganism in Egypt: the last Buchis was buried on November 4, $340 \mathrm{CE}$, during the reign of Constans II (Grenier 1983). North of this area, on the site of Baqaria, the Buchis' mothers were also buried (Grenier 2002; 2003).

As lord of Armant, Montu was attested since the First Intermediate Period in the Theban Tomb 186. The theology of Montu was clearly influenced by Heliopolitan tradition, as Armant was the "Southern Heliopolis." Thereby, Montu was a solar god, especially in his name of Montu-Re (until the Ramesside Period) and Montu-Re-Horakhty. As a warrior god, he was worshipped also in the temples of Tod, Medamud, and North-Karnak, these three cities with Armant ("Theban Palladium") having been charged with the protection of the city of Thebes. Montu was also venerated as a form of Osiris at Armant, especially in the Ptolemaic crypts, which seems closely linked to the Djemaic rituals from Medinet Habu: once a year, on the twenty-fourth day of the month of Khoiak, Montu from Armant visited Amun and the primaeval gods of the mound of Djeme (Thiers and Volokhine 2005). In the crypts he was "Montu-Re, lord of Armant, king of the gods, Osiris whose limbs are completed, father of the fathers of all the gods."

SEE ALSO: Amenemhat I-VII; Mentuhotep I-VII; Nektanebo; Rameses I-XI; Re/Ra, Re-Horakhte; Senwosret (Sesostris) I-IV; Sety (Seti) I-II; Thutmose I-IV.

\section{REFERENCES AND SUGGESTED READINGS}

Betro, M. (2001) Armant dal I Periodo Intermedio alla fine del Nuovo Regno. Prosopografia. Pisa.

Beylage, P. (2002) Aufbau der königlichen Stelentexte vom Beginn der 18. Dynastie bis zu Amarnazeit. Wiesbaden.
Engelbach, R. (1923) "A monument of Senusret Ist from Armant." Annales du Service des Antiquités d'Égypte 23: 161-2.

Farid, A. (1979) "New Ptolemaic blocks from Rub'-el-Maganin-Armant.” Mitteilungen des Deutschen Archäologischen Instituts, Abteilung Kairo 35: 59-74.

Farid, A. (1983) "A preliminary report on the clearance of the Temple of Monthu and Re'it-Taui at Armant. Season July-August 1980." Orientalia Antiqua 22: 67-72.

Farid, A. (1983) "Two New Kingdom statues from Armant.” Mitteilungen des Deutschen Archäologischen Instituts, Abteilung Kairo 39: 59-69.

Gardiner, A. H. (1955) "Blocks from the temple of Tuthmosis III at Armant.” In E. Breccia, ed., Studia in Memoria di Ippolito Rosellini nel primo centenario della morte (4 giugno 1843-4 giugno 1943) 2: 91-8. Pisa.

Grenier, J.-Cl. (1983) "La stèle funéraire du dernier taureau Bouchis (Caire JE 31901 = Stèle Bucheum 20)." Bulletin de l'Institut Français d'Archéologie Orientale 83: 197-208.

Grenier, J.-Cl. (2002) "La stèle de la mère d'un Bouchis datée de Licinius et de Constantin." Bulletin de l'Institut Français d'Archéologie Orientale 102: 247-59.

Grenier, J.-Cl. (2003) "Remarques sur les datations et titulatures de trois stèles romaines du Bucheum." Bulletin de l'Institut Français d'Archéologie Orientale 103: 267-79.

Grenier, J.-Cl. (2009) "Les pérégrinations d'un Boukhis en Haute Thébaïde." In C. Thiers, ed., Documents de théologies thébaines tardives (D3T 1): 39-48. Montpellier.

Grossmann, P. (1986) "Zum Grundriß der Basilika von Armant (Hermonthis)." In Studien zur spätantiken und byzantinischen Kunst, Fs. Friedrich Wilhelm Deichmann, vol. 1: 143-53. Mainz am Rhein.

Grossmann, P. (2007) "Spätantike und frühmittelalterliche Baureste im Gebiet von Ermant. Ein archäologischer Survey." Journal of Coptic Studies 9: 1-20.

Mond, R. and Myers, O. H. (1934) The Bucheum. London.

Mond, R. and Myers, O. H. (1940) Temples of Armant: a preliminary survey. London.

Sourouzian, H. (2005) "Features of early Twelfth Dynasty royal sculpture." Bulletin of Egyptian Museum 2: 103-24. 
Thiers, C. (2007) "Missions épigraphiques de l'Ifao dans les villes méridionales du Palladium thébain." In J.-Cl. Goyon and Chr. Cardin, eds., Actes du neuvième congrès international des égyptologues, 6-12 septembre 2004 Grenoble: 1807-16. Leuven.

Thiers, C. (2009) "Fragments de lions-gargouilles d'Ermant." In C. Thiers, ed., Documents de théologies thébaines tardives (D3T 1): 147-65. Montpellier.

Thiers, C. and Volokhine, Y. (2005) Ermant, vol. 1: Les cryptes du temple ptolémaïque. Étude épigraphique. Cairo.

Web sites:

http://recherche.univ-montp3.fr/egyptologie/ermant. http://www.ifao.egnet.net/archeologie/ermant. 